\title{
sciendo
}

\section{$\beta$-GLUCAN AS A PROMISING FOOD ADDITIVE AND IMMUNOSTIMULANT IN AQUACULTURE INDUSTRY - A REVIEW}

\author{
Mohammad Hossein Khanjani ${ }^{1 \star}$, Moslem Sharifinia ${ }^{2}$, Gholamreza Ghaedi ${ }^{3}$ \\ ${ }^{1}$ Department of Fisheries Sciences and Engineering, Faculty of Natural Resources, University of Jiroft, Jiroft, Kerman, Iran \\ ${ }^{2}$ Shrimp Research Center, Iranian Fisheries Sciences Research Institute, Agricultural Research, Education and Extension Organization \\ (AREEO), Bushehr 75169-89177, Iran \\ ${ }^{3} \mathrm{Ph} . \mathrm{D}$. in Aquaculture, Graduated from Khorramshahr University of Marine Science and Technology, Khorramshahr, Iran \\ •Corresponding author: m.h.khanjani@ujiroft.ac.ir, m.h.khanjani@gmail.com
}

\begin{abstract}
The use of antibiotics in aquatic feed reduces the incidence of disease and enhances growth performance, although it presents harmful effects, such as development of resistant bacteria and accumulation in the natural environment. A variety of immune stimulants including probiotics, prebiotics, synbiotics, phytobiotics, organic acids, nucleotides, antioxidants, microalgae, yeast and enzymes have been used in the aquaculture industry. In recent decades, much attention has been paid to find a variety of immunostimulants with lower cost which also affect specific and non-specific immunity and improve fish resistance against a wide range of pathogens. These stimulants strengthen the fish's immune system by increasing the number of phagocytes, lysozyme activity and level of immunoglobulin. The use of immune stimulants as an effective tool to overcome diseases and strengthen the immune system of farmed species, leads to the promotion of cellular and humoral defense mechanisms and increases resistance to infectious diseases. Among these immunostimulants used in aquaculture, $\beta$-glucans are of particular importance. Glucans are complex polysaccharide compounds extracted from the cell wall of yeasts and fungi. These compounds can stimulate fish growth, survival, and immune function. Therefore, this review discusses the role and importance of $\beta$-glucan as a food additive in aquaculture and examines the impact of these compounds on the growth performance, immunity and biochemical parameters of farmed species.
\end{abstract}

Key words: $\beta$-glucan, nutrition, immunity, growth performance, aquaculture, food additive

In recent years, the aquaculture industry has developed rapidly and provides fish products for human consumption (Khanjani et al., 2020 a; Khanjani and Sharifinia, 2020, 2021; Pauly and Zeller, 2017). By 2030, aquaculture is expected to provide about $62 \%$ of fish for human consumption. In addition, after 2030, aquaculture is likely to continue to dominate global fish supply in the future and grow steadily (Kobayashi et al., 2015). To meet human demand, the aquaculture industry is moving towards intensification, which can lead to new challenges in the aquaculture industry. As in other farming sectors, with the intensification and expansion of aquaculture activities, the likelihood of major disease problems increases. Therefore, the aquaculture industry is full of its share of diseases and problems caused by viruses, bacteria, fungi, parasites and other pathogens that have not been detected and are emerging. There is currently intense pressure from society and consumers to find alternatives to antibiotic treatment to prevent or reduce the effects of disease on aquaculture without affecting their health and quality (Carbone and Faggio, 2016). The use of immunostimulants through dietary supplements is a major area of research for farmed aquatic species (Lee et al., 2020 a; Ma et al., 2020; Terzi et al., 2020).
Different types of immunostimulants have been studied, but few of them are suitable for aquaculture, and many of these immunostimulants are not used in aquaculture due to their high cost and low impact (Caipang and Lazado, 2015; Ringø et al., 2012). Immunostimulants are effective in increasing the growth performance, survival rate and immune system of aquatic organisms, and many of them are significant in aquaculture, including compounds such as $\beta$-glucans, alginates, nucleotides, vitamin $\mathrm{C}$, aquatic and terrestrial plant extracts, and microbial accumulations (biofloc) (Dawood et al., 2018; Ghaedi et al., 2015; Khanjani et al., 2021 a, b, c; Khanjani and Sharifinia, 2020; Khanjani et al., 2020 b; Mohan et al., 2019; Wang et al., 2017 b). Among these immunostimulants used in aquaculture, $\beta$-glucans are of particular importance. Glucan is a homopolysaccharide composed of glucose molecules linked together by a glycosidic bond. In general, glucan molecules are divided into two categories based on their type of glycosidic bonds: alpha-glucan bonds include dextran and starch, and $\beta$-glucan bonds include cellulose, zymogen, laminarin, and lichen (Bagni et al., 2005; Soltanian et al., 2009). Due to their complex structure, $\beta$-glucans have an extraordinary ability to activate the immune system (Bagni et al., 2005; Soltanian 
et al., 2009). It is an important cell wall compound of a number of plants, fungi, bacteria, yeasts and seaweeds (Sonck et al., 2010). Various studies on fish have shown that $\beta$-glucan is a valuable immunostimulant for improving immune status and disease control in farmed aquatic animals (Bricknell and Dalmo, 2005; Medina-Gali et al., 2018; Meena et al., 2013; Russo et al., 2006; Selim and Reda, 2015; Sherif and Mahfouz, 2019).

In nature, $\beta$-glucans are abundant in the cell wall of many plants (such as wheat, rye, barley and oats), yeast (Saccharomyces) and genera of the Echinacea family (Sirimanapong et al., 2015; Thompson, 2017). Other sources of $\beta$-glucan are seaweed of the genus Laminaria, and fungi (Rop et al., 2009; Thompson, 2017). Common sources of $\beta$-glucans are derived from the cell wall of bread yeast, the most important of which are $\beta-1-3$ glucans and $\beta-1-6$ glucans (Morales-López et al., 2009). $\beta$-glucans derived from different sources have differences in their structure (Ringø et al., 2012). Barley and oat $\beta$-glucans are linear with beta $1-4$ and beta $1-3$ bindings. Fungal $\beta$-glucans have beta $1-6$ as short branches attached to the $1-3$ beta strand. Yeast $\beta$-glucans have beta $1-6$ branches that bind to beta $1-3$. These structural differences can cause differences in their extraction and performance. Higher molecular weight glucans activate leukocytes, stimulate their phagocytic, cytotoxic and antimicrobial activities, and produce oxygen free radicals. Lower molecular weight glucans have fewer cellular effects, and very short glucans are virtually inactive (Akramienè et al., 2007; Zhu et al., 2016). Studies have shown that insoluble $\beta$-glucans (1-3/1-6) have more biological activity than their soluble counterparts (1-3/1-4) (Ooi and Liu, 2000). Considering the multifaceted role of $\beta$-glucans in aquatic species this review investigates the importance of $\beta$-glucan as a food additive and immunostimulant in the aquaculture industry with emphasis on growth performance, immunity and biochemical parameters.

\section{$\beta$-glucan}

$\beta$-glucans are major bioactive compounds with anti-cancer, anti-inflammatory, and immune-modulating properties (Meena et al., 2013; Zhu et al., 2016). This compound has been increasingly used by different industries due to its specific physical properties, such as water solubility, viscosity, and gelation (Meena et al., 2013; Zhu et al., 2016). $\beta$-glucans play an important role in activating innate and acquired immunity. The innate immune responses stimulated by $\beta$-glucans not only act on invading microorganisms but also complement the activation and function of acquired immunity (Montoya et al., 2018; Sakai, 1999; Velazquez-Carriles et al., 2018). The induction of the cellular response by $\beta$-glucan depends on the specific reactions of one or more cell surface receptors. Glucans are believed to enhance innate immunity by binding to specific receptors on monocytes/ macrophages, neutrophils, and natural killer cells (Mueller et al., 2000).
Because of their ability to bind directly to macrophages and other white blood cells, such as neutrophils and natural killer cells, and activate them, they provide good resistance to any invader (Gantner et al., 2003; Herre et al., 2004). When $\beta$-glucan receptors are involved with $\beta-1-3 / 1-6$ glucan, there is a general improvement in immune parameters, such as phagocytosis, release of specific cytokines (intracellular hormones), interferons, and antigen preparation. Cytokines can stimulate the formation of new white blood cells (Raa, 2000). Phagocytic cells and activated white blood cells produce cytokines and antibodies, respectively, and increase the effectiveness of vaccines (Raa, 2000). Specific properties of glucans such as stimulating the immune system without over-activating it (Liu et al., 2020) and its ability to reduce high cholesterol levels (Joyce et al., 2019; Wang et al., 2017 c) make it a unique immunostimulant.

\section{The function of $\beta$-glucan in improving immunity}

$\beta$-glucan plays an important role in activating the innate and acquired immune system. The presence of glucan receptors on macrophages and other white blood cells (neutrophils and natural killer cells) has been reported (Gantner et al., 2003; Herre et al., 2004). When glucan binds to these cells with its receptors, it activates macrophages directly (Sakai, 1999) and then all immune mechanisms, including phagocytosis, release of specific cytokines such as interleukin-1, interleukin-6, GM-CSF and interferons are activated. These cytokines stimulate the production of new white blood cells and thus increase $\beta$-glucan receptors (Meena et al., 2013). The results of immune indices in the serum show that lysozyme, immunoglobulin $\mathrm{M}$ (IgM), total immunoglobulin and alternative pathway (ACH50) were improved in rainbow trout (Oncorhynchus mykiss) broodstocks fed with $0.2 \%$ $\beta$-glucan (Ghaedi et al., 2015). The effect of $\beta$-glucan on increasing lysozyme levels has also been reported in other studies, including Atlantic salmon (Salmo salar) (Engstad et al., 1992), large yellow croaker (Pseudosciaena crocea) (Ai et al., 2007) and Indian carp (Labeo rohita) (Misra et al., 2006). Increased lysozyme activity is probably due to increased white blood cell counts and macrophage activity. When $\beta$-glucan binds to macrophages and other white blood cells, such as neutrophils, with its receptors, it activates macrophages and forms white blood cells (Meena et al., 2013). As a result, this increase in the number of macrophages increases lysozyme secretion (Sahoo et al., 2005).

Complement $(\mathrm{C})$, among them $\mathrm{C} 3$, is a main component of the innate immune system that plays an important role in the acquired immune system (Morgan et al., 2005). Complement contains about 30 to 35 soluble and membrane proteins that perform different functions and protect embryos and larvae before the completion of immune system (Ogundele, 2001; Wang et al., 2008) and they are given the ability to fight against pathogens (Løvoll et al., 2006). Complement proteins are activated in three overlapping ways: the classical, secondary, 
and lectin methods (Holland and Lambris, 2002; Nonaka and Smith, 2000). The amount of C3 in rainbow trout broodstocks (O. mykiss), as a representative of the classical method, was not affected by different amounts of $\beta$-glucan, but the alternative pathway (ACH50) was increased (Ghaedi et al., 2015). Some studies have reported that $\beta$-glucan injection activates the alternative pathway (Engstad et al., 1992; Travassos and Taborda, 2017 ) but $\beta$-glucan nutritional supplementation does not promote the same effect (Ai et al., 2007; Ortuño et al., 2002). They stated that the injection of $\beta$-glucan causes inflammatory reactions resulting in the synthesis of acute phase proteins including complement factors from the liver, but nutrition with $\beta$-glucan does not cause this type of reaction. Furthermore, Dalmo and Bøgwald (2008) reported that non-specific immune indices such as ACH50 and lysozyme increase under the influence of $\beta$-glucan. Nevertheless, Verlhac et al. (1998) reported that the use of $\beta$-glucan in the diet of rainbow trout had no effect on respiratory burst, pinocytosis, lysozyme activity, and alternative pathway of complement. In addition, Ogier de Baulny et al. (1996) stated that long-term feeding of turbot (Scophthalmus maximus) with glucan had no effect on complement and lysozyme activity. These conflicting reports on the effects of $\beta$-glucan can be due to reasons such as the dose, the duration of feeding, or the life stage of the species. In addition, commercial $\beta$-glucans that have different manufacturing processes, as well as the type of species, which can cause differences in test results and immune system reactions (Ai et al., 2007; Bridle et al., 2005).

Studies that have examined the effects of immunostimulants have reported an increase in immunoglobulin M. For example, the use of immunostimulants such as vitamin A, chitin, yeast and levamisole in seabream (Sparus aurata) has increased immunoglobulin M level (Cuesta et al., 2004), as well as feeding $0.1 \%$ glucan in rohu (Labeo rohita) increased specific and non-specific immune factors (Sahoo and Mukherjee, 2001). Nutrition with glucan raises the production of white blood cells (Meena et al., 2013) which in turn increases lymphocytes $\mathrm{B}$ and the production and secretion of immunoglobulin M (Ross et al., 1998). Immunoglobulin M transfer process is from broodstocks to the eggs through the blood to the follicle, which depends on the difference in immunoglobulin (Ig) concentration. The presence of immunoglobulin $\mathrm{M}$ in plasma and blood during ovarian maturation and the increase in serum Ig concentration during the reproductive period in many fish confirm the oocyte transfer (Kanlis et al., 1995; Picchitti et al., 2001; Scapigliati et al., 1999).

\section{及-glucan function in biochemical indicators}

Misra et al. (2006) investigated the effects of multiple injections of $\beta$-glucan on non-specific immune response and disease resistance in Labeo rohita fingerlings and reported an increase in total protein, globulin and albumin/ globulin percentage after feeding with $0.025 \% \beta$-glucan.
Furthermore, Ghaedi et al. (2015) found that biochemical parameters including protein, albumin and globulin in $\beta$-glucan-fed rainbow trout broodstocks were higher than control-fed broodstocks. Given that these parameters are important compounds in the immune system and are associated with nonspecific immunity (Kumar et al., 2005), their increase indicates the proper function of $\beta$-glucan as an immunostimulant. Total protein and globulin are needed to keep the immune system healthy, and these parameters are usually higher in fish fed with immunostimulant (Choudhury et al., 2005). Abdel-Tawwab et al. (2008) concluded that as the yeast in the feed of the Nile tilapia (Oreochromis niloticus) increased, the levels of these indices increased. In addition, Amparyup et al. (2012) also stated that pattern recognition proteins [including lipopolysaccharide and $\beta$-1,3-glucan binding protein (LGBP)] could raise the phenoloxidase activity in black tiger shrimp (Penaeus monodon).

\section{$\beta$-glucan function in growth performance}

The effects of $\beta$-glucan alone or in combination with other immunostimulants on growth performance and survival have been examined by several researchers. For instance, Nile tilapia (Oreochromis niloticus) fed with different concentrations of $\beta$-glucan indicated no difference in growth and survival rate after 10 weeks (Whittington et al., 2005). $\beta$-glucan at a dose of $250 \mathrm{mg} / \mathrm{kg}$ diet was recommended for enhancing immunity, growth, and survival against opportunistic pathogens such as $A e-$ romonas hydrophila and Edwardsiella tarda in rohu ( $L a-$ beo rohita). Oral administration of three different quantities of $\beta$-glucan, low $(38 \mathrm{~g} / \mathrm{kg})$, average $(52 \mathrm{~g} / \mathrm{kg})$ and high $(82 \mathrm{~g} / \mathrm{kg})$ in Oncorhynchus mykiss showed decrease in the growth rate but enhanced survival against IHNV (infectious hematopoietic necrosis virus) (Sealey et al., 2008). Pacific white shrimp (Litopenaeus vannamei) fed with diet containing inactive yeast cell wall ( $\beta$ - glucan) 1 and $2 \mathrm{~g} / \mathrm{kg}$ feed showed no significant differences in final weight, survival, and growth rate, but indicated better effects on immune parameters compared to the control group (Chotikachinda et al., 2008). These differences in results are due to different types of $\beta$-glucan, dosage, route and duration of administration, as well as aquatic animal species.

Growth indices in rainbow trout larvae fed $\beta$-glucan were higher than the control group (Ghaedi et al., 2015). In Pseudosciaena crocea, an increase in growth due to feeding with $\beta$-glucan at a $0.09 \%$ supplementation level was reported, but the $0.18 \%$ level had no effects (Ai et al., 2007). These results are also consistent with those obtained from hybrid bass (Morone chrysops $\times$ M. saxatilis) (Li and Gatlin III, 2003, 2004, 2005), Indian carp (Misra et al., 2006), Penaeus monodon (Chang et al., 2003) and Nile tilapia. Some studies have also reported that adding yeast to the diet improves diet and protein digestion (Lara-Flores et al., 2003; Tovar et al., 2002; Waché et al., 2006). Increased survival and growth under $\beta$-glucan is probably due to increased disease resistance as a result 
of enhanced immunity (Itami et al., 1989) or improved digestive function (Abdel-Tawwab et al., 2008). Another explanation could be the selective fermentation of the polysaccharide by probiotic bacteria. This, in turn, would provide health benefits to the host (Lam and Cheung, 2013).

Large yellow croakers fed with $\beta$-glucan at $0.09 \%$ reduced the mortality rate compared to the control group (Ai et al., 2007). The increase in relative survival in juveniles is possibly due to increased immunity, which has been reported in other studies on glucan (Castro et al., 1999; Chen and Ainsworth, 1992; Cook et al., 2001). An adequate amount of glucan can improve immunity and increase disease resistance in fish.

\section{Review of studies}

Table 1 lists some of the studies performed with $\beta$-glucan. Ai et al. (2007) examined the effects of $\beta$-glucan on growth and innate immunity indices in Pseudosciaena crocea. Three diets (0, 0.09 and $0.18 \%)$ were used and growth indices, lysozyme activity, alternative pathway of complement, phagocytosis percentage and respiratory burst activity were measured. The results of their study showed that $0.09 \%$ of glucan in the diet has the best effect on increasing immunity and immune parameters were not significantly different when comparing the control group and the $0.18 \%$ supplementation.

Bagni et al. (2005) investigated the effects of Macrogard $\beta$-glucan and an alginic acid-containing algae extract called Ergosan on immune parameters including complement, lysozyme, total protein and heat shock proteins (HSP) in seabass (Dicentrarchus labrax). The results of the study showed that Macrogard and Ergosan promote the innate immunity of fish.

The IgM levels of seabream (Sparus aurata) under the influence of various immunomodulators were examined by Cuesta et al. (2004). In this study, they investigated several substances including vitamin A, chitin, yeast or levamisole as immunostimulants and in high stocking density conditions, hypoxia and anesthetics as stressors. Immunostimulants increased serum IgM but density and hypoxia had no effect on IgM levels. Anesthetics including benzocaine and phenoxyethanol decreased $\operatorname{IgM}$ but quinaldine increased IgM. Sahoo and Mukherjee (2001) studied the effects of glucan on rohu (Labeo rohita), arguing that feeding healthy fish with glucan increased specific, non-specific immunity and resistance to Aeromonas hydrophila. Verlhac et al. (1998) by studying vitamin C and glucan alone or in combination on the immune indices of rainbow trout, reported that vitamin $\mathrm{C}$ and glucan alone or in combination significantly increased innate immune indicators such as phagocytic activity and lysozyme.

Siwicki et al. (1994) investigated the effects of immunostimulants including Macrogard, Candida utilis, Saccharomyces cerevisiae, Evetsel, Chitosan, and Finnstim on the immune parameters of $200 \mathrm{~g}$ rainbow trout and observed an increase in the release of oxidative radicals, myeloperoxidase activity, phagocytosis and the lethal activity of phagocytic cells such as neutrophils. Total plasma protein and total immunoglobulin rose under the influence of these stimuli. Bacterial challenge with Aeromonas salmonicida also showed that fish fed these stimuli were more resistant to infection

The effects of dietary $\beta$-glucan in silver catfish (Rhamdia quelen) were investigated by Domenico et al. (2017). They stated that $\beta$-glucan had no effect on growth performance and blood cells, serum bacterial agglutination and serum myeloperoxidase activity. However, the natural hemolytic activity of complement in $\beta$-glucan treatment increased significantly compared to the control group. In addition, fish of the $\beta$-glucan treatment were challenged with $A$. hydrophila and showed fewer bacteria in blood and presented a significantly higher survival rate compared to the control group.

Tayyab et al. (2019) evaluated the effects of $\beta$-glucan, the plant extract, Vitabio A, and the plant extract with probiotic Lactobacillus spp. (Vitabio B) on the growth, histology and immune response of rohu (Labeo rohita). They concluded that the plant extracts and $\beta$-glucan can be used without any adverse effects on growth, total serum proteins, hematology and fish body composition.

Effect of glucan on growth, survival, digestive enzyme activity, immune system and intestinal barrier gene expression for tropical gar (Atractosteus tropicus) juveniles was experimented by Nieves-Rodríguez et al. (2018). Their results indicated that $0.5 \%$ to $1.5 \%$ of $\beta$-glucans in the diet had no adverse effects. They also expressed that $\beta$-glucan $1,3 / 1,6$ at $1.0 \%$ and $1.5 \%$ in the diet significantly increases chymotrypsin activity.

Sirimanapong et al. (2015) investigated the effects of $\beta$-glucan on the immune response of pangasius (Pangasianodon hypophthalmus) and concluded that both the innate humoral and cellular immune responses of pangasius were differentially stimulated by different concentrations of $\beta$-glucan, with doses of 0.1 or $0.2 \%$ fungal-derived $\beta$-glucan giving optimal immunostimulation compared with the basal diet, and these performed equally well as fish fed $0.1 \%$ commercial yeast-derived $\beta$-glucan.

Adloo et al. (2015) studied the effect of different levels of $\beta$-glucan on the growth performance, survival and physiological responses in juvenile pangasius (Pangasianodon hypophthalmus). They stated that different levels of $\beta$-glucan had no significant effect on the growth, survival and glucose value of fish. However, highest serum lysozyme activity was measured in fish fed on a diet containing $0.5 \%$ of $\beta$-glucan. Furthermore, the protein content was significantly enhanced in all $\beta$-glucan treatments compared to the control group.

Ghaedi et al. (2015) examined the effect of $\beta$-glucan on broodstocks, larvae and maternal immunity in rainbow trout and reported that the immune parameters of female broodstocks at $0.2 \%$ glucan were significantly higher than the control group. They also stated that some immune parameters were transferred to oocytes. 
Table 1. A summary of the effects of $\beta$-glucan on cultured aquatic animals in different studies

\begin{tabular}{c|c|c|c}
\hline Species & Findings & Reference \\
\hline 1 & 2 & 3 \\
\hline
\end{tabular}

African catfish

(Clarias gariepinus)

Atlantic salmon (Salmo salar)

Atlantic salmon

Blue swimmer crab

(Portunus pelagicus)

Common carp

(Cyprinus carpio)

Gilthead seabream

(Sparus aurata)

Hybrid giant tiger groupers

(Epinephelus fuscoguttatus $\times$

Epinephelus lanceolatus)

Hybrid striped bass (Morone

chrysops $\times$ M. saxatilis)

Koi carp (Cyprinus carpio koi)

Large yellow croaker

(Pseudosciaena crocea)

Marron (Cherax tenuimanus)

Mozambique tilapia

(Oreochromis mossambicus)

Mozambique tilapia

Nile tilapia (Oreochromis niloticus)

Nile tilapia

Nile tilapia

Nile tilapia

Nile tilapia

Nile tilapia

Nile tilapia
In exposure to chlorpyrifos, the algae Spirulina platensis and $\beta$-glucan inhibit Mokhbatly et al. (2020)

the effects of chlorpyrifos on health status, immunity, and antioxidative responses of African catfish

Atlantic salmon are more resistant to a vaccine against pathogens when diets Roberti Filho et al. (2019) rich in $\beta$-glucans are consumed

$\beta-1,3 / 1,6$ glucan-containing diets increased the levels of transcripts of key Rodríguez et al. (2016) genes involved in the immune response of salmon, allowing it to respond more strongly to a vaccine, as well as decreasing the effect of hypoxia

The functional aspects of b-GBP purified from P. pelagicus and its vital role in Anjugam et al. (2016) triggering prophenoloxidase during pathogenic infection were described

A diet based on plant oils did not significantly impair the immunomodula- Nguyen et al. (2019) tory effects of $\beta$-glucans, proving that these oils are suitable for sustaining a high level of immunity in common carp

In a Mediterranean aquaculture system, the $\beta$-1,3/1,6-glucan and Pdp 11 (She- Guzmán-Villanueva et al. wanella putrefaciens, a probiotic isolated from gilthead seabream skin) modu- (2014 b)

lated immunity and promoted the growth of gilthead seabream

$\beta$-glucan can alleviate the immunosuppressive effects mediated by oxytetracy- Lee et al. (2020 b)

cline (OTC) in vitro. Dietary $\beta$-glucan in combination with OTC improves the

parameters of innate immunity. A combination of $\beta$-glucan and OTC provides better protection against bacterial infection than either alone

During feeding trials, a synergistic effect between $\beta-1,3$ glucan paramylon and Yamamoto et al. (2020) vitamin $C$ was most noticeable in vitro in terms of reactive oxygen species, and a limited enhancement of immune responses was observed in vivo

Koi’s immune responses were improved and they were less susceptible to in- Lin et al. (2011) fection from Aeromonas veronii when given immunostimulants through dietary intake. In particular, supplementing the kois with $\beta-1,3$ glucan for 56 days resulted in significant improvements in growth, survival, and immune response

$\beta$-glucan was able to reduce hypoxia-induced oxidative stress in large yellow Zeng et al. (2016) croaker through enhancing anaerobic glycolysis capacity, highlighting HIF-1 a's role in this process

Marron's immune system may be improved by increasing dietary $\beta-1,3$ glucan Sang and Fotedar (2010) concentrations to a minimum of $0.1-0.2 \%$

A dietary supplementation of $0.004 \%$ - 1,3 glucan binding protein based zinc Anjugam et al. (2018) oxide nanoparticles may have a positive effect on the immune system and survival of $O$. mossambicus.

Acquiring stress tolerance and improving aquaculture growth performance of Divya et al. (2020) Mozambique tilapia can be accomplished with $\beta$-glucan out of yeast, Saccharomyces cerevisiae

The fish immune status and relative level of protection were significantly im- Sherif and Mahfouz (2019) proved by $\beta$-glucan. To achieve better fish growth and disease resistance, new feeding practices in fish farming should include various additives

The results show that the concentration of $0.1 \mathrm{mg} \mathrm{L}^{-1}$ increased tolerance to de Souza et al. (2020) hypoxia, increased survival rates, and regulated glucose levels of Nile tilapia. Before hypoxic challenge, a concentration of $0.3 \mathrm{mg} \mathrm{L}^{-1}$ modulates the hematological responses under stress and increases the lymphocyte count

The $\beta$-glucan diet can improve the growth, intestinal morphometry, stress re- Dawood et al. (2020) sistance, and immunity of Nile tilapia aquaculture by counteracting the negative effects of crowding stress

Dietary $\alpha$-lipoic acid, $\beta$-glucan, and L-carnitine have varying protective mech- Lu et al. (2019) anisms and different effectiveness against $A$. hydrophila infections in Nile tilapia

$\beta$-glucan supplementation alleviated the immune-toxic and antioxidant effects Abd El Hakim et al. (2019) of fipronil in tilapia

Atrazine negatively impacts immune responses, antioxidant balance, and genes Neamat-Allah et al. (2020) related to them for Nile tilapia. It is possible that supplementing with $\beta$-glucan before exposure to atrazine can help counteract the damage caused by atrazine water pollution compared to its simultaneous treatment with atrazine.

Further evidence of $\beta$-glucans' use in aquaculture, specifically Nile tilapia, is Pilarski et al. (2017) provided by these findings. In addition, they provide more evidence of the compound's growth promoting properties 


\begin{tabular}{|c|c|c|}
\hline 1 & 2 & 3 \\
\hline Nile tilapia & $\begin{array}{l}\text { The combination of Chlorella vulgaris and } \beta \text {-glucan is a potential feed ad- } \\
\text { ditive for improving immunity, prevention against oxidative damage, growth } \\
\text { performance, and hematobiochemical alterations induced by diazinon toxicity } \\
\text { in Nile tilapia }\end{array}$ & Abdelhamid et al. (2020) \\
\hline Nile tilapia & $\begin{array}{l}\text { A study conducted on Nile tilapia showed that } \beta \text {-glucan administration allevi- } \\
\text { ated the negative effects of chlorpyrifos on immunity, anti-inflammatory re- } \\
\text { sponse, and histopathology }\end{array}$ & Dawood et al. (2020) \\
\hline Nile tilapia & $\begin{array}{l}\text { As a result of the } \beta \text {-glucan treatment, Nile tilapia larvae were } 20 \% \text { heavier and } \\
8.5 \% \text { longer compared to controls }\end{array}$ & de Jesus et al. (2019) \\
\hline $\begin{array}{l}\text { Olive flounder (Paralichthys } \\
\text { olivaceus) }\end{array}$ & $\begin{array}{l}\text { Olive flounder mortality from bacterial and viral infections was reduced as a } \\
\text { result of innate immune function activation by } \beta-1,3 \text {-glucan. Scuticociliatosis- } \\
\text { related death, however, did not appear to be protected by the same level of im- } \\
\text { munity. This pronounced response against bacterial infection suggests bacterial } \\
\text { pathogens are dealt with by factors other than innate immunity }\end{array}$ & Lee et al. (2018) \\
\hline $\begin{array}{l}\text { Pacific red snapper (Lutjanus } \\
\text { peru) }\end{array}$ & $\begin{array}{l}\text { The addition of 1,3/1,6-glucan to Pacific red snapper feed increased growth, } \\
\text { antioxidant activity, and digestive enzyme activity }\end{array}$ & $\begin{array}{l}\text { Guzmán-Villanueva et al. } \\
\text { (2014 a) }\end{array}$ \\
\hline $\begin{array}{l}\text { Pacific white shrimp (Litope- } \\
\text { naeus vannamei) }\end{array}$ & $\begin{array}{l}\text { In } L . \text { vannamei, dietary } \beta \text {-glucan supplements at } 0.02 \%-0.04 \% \text { can signifi- } \\
\text { cantly boost digestibility, antioxidant capacity, and immunity, thus improving } \\
\text { growth performance and survival under low salinity conditions. The beneficial } \\
\text { effects of } \beta \text {-glucan probably result from probiotics dominating potential patho- } \\
\text { gens in the intestine }\end{array}$ & Li et al. (2019) \\
\hline Pacific white shrimp & $\begin{array}{l}\text { Based on the evidence, } \beta-1,3 / 1,6 \text {-glucan and vitamin } \mathrm{C} \text { were shown to induce } \\
\text { nonspecific immune responses in Pacific white shrimp in an additive manner }\end{array}$ & Wu et al. (2016) \\
\hline Pacific white shrimp & $\begin{array}{l}\text { Pediococcus acidilactici combined with } \beta \text {-glucan or } \beta \text {-glucan alone influenced } \\
\text { shrimp growth and protein composition in meat. The concentration of haemo- } \\
\text { lymph glucose and osmoregulation were also increased by dietary } \beta \text {-glucan. } \\
\text { Adding a synbiotic supplement had more impact on intestinal morphometry } \\
\text { and microbiota than consuming } \beta \text {-glucan on its own }\end{array}$ & $\begin{array}{l}\text { Boonanuntanasarn et al. } \\
\text { (2016) }\end{array}$ \\
\hline
\end{tabular}

Pacific white shrimp

$\beta$-glucans obtained from marine yeasts living in the shrimp pond provided ex- Ochoa-Álvarez et al. tra protection against the mortalities caused by this pathogenic virus

Pacu (Piaractus mesopotami- $\quad$ The results of this study support the benefits of feeding strategies that integrate Soares et al. (2018) cus)

both mannans and 1,3-1,6 glucans as dietary supplements prior to intensive management. In the 30-day period, growth performance was increased, nutrient utilization was improved, stress responses were minimized, and immunity responses were modulated for pacu fed the dietary supplements

Pacu

$\beta$-glucans and mannanoligosaccharides in a $0.2 \%$ composition promoted the Hisano et al. (2018) best responses to feed, feed efficiency, and intestinal morphology in juvenile pacu, without detrimental effects on hematological parameters

Pacu

In addition to reducing the activity of leukocytes after stress and the bacte- Sabioni et al. (2020)

rial challenge, $\beta$-glucan increased the level of baseline glucose in the blood of pacu. Glucan is confirmed to have immunomodulatory effects and may be involved in stress response

Pacu

The $\beta$-glucan modulated the bidirectional interaction between stress and im- de Mello et al. (2019) munity. As the levels of cortisol and the immune system were modulated at various times in their study, this suggests that the compound is protective by preventing high levels of the hormone and enhancing immunity to bacterial infection in pacu

Pengze crucian carp (Carassius Supplementation with $\beta$-glucan and Bacillus subtilis significantly increased the Cao et al. (2019) auratus) antioxidant status, immune response, and fillet quality of Pengze crucian carp

Persian sturgeon (Acipenser $\quad$ Persian sturgeon can benefit from $\beta$-glucan as a dietary supplement to improve Aramli et al. (2015) persicus) their immune response and growth performance

Pompano (Trachinotus ovatus) By supplementing $\beta$-glucans, the pompano fish T. ovatus grew faster, had high- Do Huu et al. (2016) er Vibrio counts, and was more resistant to stress

Rainbow trout (Oncorhynchus Based on the results of this study, dietary $\beta$-glucans at $0.1 \%$ and $0.2 \%$ are Ji et al. (2017) mykiss) beneficial for increasing growth in rainbow trout and improving resistance to Aeromonas salmonicida. Furthermore, $\beta$-glucan may play a critical role in the regulation of stress- and immune-related factors in rainbow trout, making it more effective in fighting bacterial infection

Rainbow trout

The effects of $\beta$-glucan at concentrations of $0.1 \%$ and $0.2 \%$ were dose-depend- Ji et al. (2019) ently ameliorated in rainbow trout from trinitrobenzene sulfonic acid-induced enteritis. This study provides evidence supporting the use of $\beta$-glucan in treating or protecting fish enteritis 


\begin{tabular}{|c|c|c|}
\hline 1 & 2 & 3 \\
\hline Rainbow trout & $\begin{array}{l}\text { The findings provide basic information to understand possible mechanisms of } \\
\text { dietary } \beta \text {-glucan's role in maternal immunity and the growth of rainbow trout }\end{array}$ & Ghaedi et al. (2016) \\
\hline $\begin{array}{l}\text { Red drum (Sciaenops ocel- } \\
\text { latus) }\end{array}$ & $\begin{array}{l}\text { In both ex vivo and in vivo studies, algamune }{ }^{\mathrm{TM}} \beta \text {-glucan was demonstrated to } \\
\text { have a moderate immunostimulatory effect on red drum }\end{array}$ & Yamamoto et al. (2018) \\
\hline Red seabream (Pagrus major) & $\begin{array}{l}\text { Supplementation with } \beta \text {-glucan and vitamin } C \text { to the basal diet of red sea bream } \\
\text { could boost the fish's growth, antioxidant reserves, humoral immunity, and } \\
\text { resistance to low salinity stress }\end{array}$ & Dawood et al. (2017 b) \\
\hline Red seabream & $\begin{array}{l}\text { P. major grows faster, is more resistant to stress, and has a better immune re- } \\
\text { sponse when its diet is supplemented with } \beta \text {-glucan }\end{array}$ & Dawood et al. (2017 a) \\
\hline $\begin{array}{l}\text { Turbot (Scophthalmus maxi- } \\
\text { mus) }\end{array}$ & $\begin{array}{l}\text { As a promising therapeutic agent, } \beta \text {-glucans can induce trained immunity } \\
\text { against bacterial disease, whereas viruses seem to take advantage of metabolic } \\
\text { changes in } \beta \text {-glucans }\end{array}$ & Librán-Pérez et al. (2018) \\
\hline Turbot & $\begin{array}{l}\text { It is concluded that MacroGard administration was immunomodulatory and } \\
\text { could be employed as a useful measure to increase survival in turbot rearing }\end{array}$ & Miest et al. (2016) \\
\hline Zebrafish (Danio rerio) & $\begin{array}{l}\beta \text {-glucan stimulates the production of lysozyme in eggs and offspring by the } \\
\text { process of transferring the molecule from mothers to eggs and by stimulating } \\
\text { the production of this molecule on oocytes of zebrafish }\end{array}$ & Wang et al. (2017 a) \\
\hline Zebrafish & $\begin{array}{l}\text { When female zebrafish were fed } \beta \text {-glucan, there was little negative effect on } \\
\text { the number of eggs and embryogenesis. For the first time, these results show } \\
\text { that } \beta \text {-glucan can help fish offspring develop non-specific immunity }\end{array}$ & Jiang et al. (2016) \\
\hline
\end{tabular}

\section{Conclusion}

The aquaculture industry is growing rapidly and its share in the total production of aquatic food has increased above $50 \%$. In order to make this growth sustainable and increase the yield and quality and thus the income, feed additives should be used.

The results of studies have shown that the addition of $\beta$-glucan to the diet can improve growth performance, survival and immunity in cultured aquatic animals. Taken together, we would strongly recommend the use of $\beta$-glucan on farmed fish diet, whenever there are sufficient evidences for its benefit, aiming to improve overall health. Optimizing the dosage of $\beta$-glucan in different cultured species should be done by more studies and improving the quality of $\beta$-glucan should be performed. The possible use of $\beta$-glucan from other sources such as seaweed, terrestrial plants and bacteria, should also be examined. $\beta$-glucan is an emerging prebiotic in aquaculture, which needs far more research to explore its roles in different species of farmed fish.

\section{References}

Abd El Hakim Y., Neamat-Allah A.N., Baeshen M., Ali H.A. (2019) Immune-protective, antioxidant and relative genes expression impacts of $\beta$-glucan against fipronil toxicity in Nile tilapia, Oreochromis niloticus. Fish Shellfish Immunol., 94: 427-433.

Abdel-Tawwab M., Abdel-Rahman A.M., Ismael N.E. (2008). Evaluation of commercial live bakers' yeast, Saccharomyces cerevisiae as a growth and immunity promoter for fry Nile tilapia, Oreochromis niloticus (L.) challenged in situ with Aeromonas hydrophila. Aquaculture, 280: 185-189.

Abdelhamid F.M., Elshopakey G.E., Aziza A.E. (2020). Ameliorative effects of dietary Chlorella vulgaris and $\beta$-glucan against diazinon-induced toxicity in Nile tilapia (Oreochromis niloticus). Fish Shellfish Immunol., 96: 213-222.
Adloo M., Soltanian S., Hafeziyeh M., Ghadimi N. (2015). Effects of long term dietary administration of $\beta$-glucan on the growth, survival and some blood parameters of striped catfish, Pangasianodon hypophthalmus (Siluriformes: Pangasiidae). Iran. J. Ichthyol., 2: 194-200.

Ai Q., Mai K., Zhang L., Tan B., Zhang W., Xu W., Li H. (2007). Effects of dietary $\beta-1,3$ glucan on innate immune response of large yellow croaker, Pseudosciaena crocea. Fish Shellfish Immunol., 22: 394-402.

Akramienė D., Kondrotas A., Didžiapetrienė J., Kèvelaitis E. (2007). Effects of ß-glucans on the immune system. Medicina, 43: 597.

Amparyup P., Sutthangkul J., Charoensapsri W., Tassanakajon A. (2012). Pattern recognition protein binds to lipopolysaccharide and $\beta$-1,3-glucan and activates shrimp prophenoloxidase system. J. Biol. Chem., 287: 10060-10069.

Anjugam M., Iswarya A., Vaseeharan B. (2016). Multifunctional role of $\beta-1,3$ glucan binding protein purified from the haemocytes of blue swimmer crab Portunus pelagicus and in vitro antibacterial activity of its reaction product. Fish Shellfish Immunol., 48: 196-205.

Anjugam M., Vaseeharan B., Iswarya A., Gobi N., Divya M., Thangaraj M.P., Elumalai, P. (2018). Effect of $\beta-1,3$ glucan binding protein based zinc oxide nanoparticles supplemented diet on immune response and disease resistance in Oreochromis mossambicus against Aeromonas hydrophila. Fish Shellfish Immunol., 76: 247-259.

Aramli M.S., Kamangar B., Nazari R.M. (2015). Effects of dietary $\beta$-glucan on the growth and innate immune response of juvenile Persian sturgeon, Acipenser persicus. Fish Shellfish Immunol., 47: 606-610.

Bagni M., Romano N., Finoia M., Abelli L., Scapigliati G., Tiscar P.G., Sarti M., Marino G. (2005). Short-and long-term effects of a dietary yeast $\beta$-glucan (Macrogard) and alginic acid (Ergosan) preparation on immune response in sea bass (Dicentrarchus labrax). Fish Shellfish Immunol., 18: 311-325.

Boonanuntanasarn S., Wongsasak U., Pitaksong T., Chaijamrus S. (2016). Effects of dietary supplementation with $\beta$-glucan and synbiotics on growth, haemolymph chemistry, and intestinal microbiota and morphology in the Pacific white shrimp. Aquac. Nutr., 22: 837-845.

Bricknell I., Dalmo R.A. (2005). The use of immunostimulants in fish larval aquaculture. Fish Shellfish Immunol., 19: 457-472.

Bridle A., Carter C., Morrison R., Nowak B. (2005). The effect of 
$\beta$-glucan administration on macrophage respiratory burst activity and Atlantic salmon, Salmo salar L., challenged with amoebic gill disease - evidence of inherent resistance. J. Fish Dis., 28: 347-356.

Caipang C.M.A., Lazado C.C. (2015). Nutritional impacts on fish mucosa: immunostimulants, pre-and probiotics, mucosal health in aquaculture. Elsevier, pp. 211-272.

Cao H., Yu R., Zhang Y., Hu B., Jian S., Wen C., Kajbaf K., Kumar V., Yang G. (2019). Effects of dietary supplementation with $\beta$-glucan and Bacillus subtilis on growth, fillet quality, immune capacity, and antioxidant status of Pengze crucian carp (Carassius auratus var. Pengze). Aquaculture, 508: 106-112.

Carbone D., Faggio C. (2016). Importance of prebiotics in aquaculture as immunostimulants. Effects on immune system of Sparus aurata and Dicentrarchus labrax. Fish Shellfish Immunol., 54: 172-178.

Castro R., Couso N., Obach A., Lamas J. (1999). Effect of different $\beta$-glucans on the respiratory burst of turbot (Psetta maxima) and gilthead seabream (Sparus aurata) phagocytes. Fish Shellfish Immunol., 9: 529-541.

Chang C.F., Su M.S., Chen H.Y., Liao I.C. (2003). Dietary $\beta$-1, 3-glucan effectively improves immunity and survival of Penaeus monodon challenged with white spot syndrome virus. Fish Shellfish Immunol., 15: 297-310.

Chen D., Ainsworth A. (1992). Glucan administration potentiates immune defence mechanisms of channel catfish, Ictalurus punctatus Rafinesque. J. Fish Dis., 15: 295-304.

Chotikachinda R., Lapjatupon W., Chaisilapasung S., Sangsue D., Tantikitti C. (2008). Effect of inactive yeast cell wall on growth performance, survival rate and immune parameters in Pacific white shrimp (Litopenaeus vannamei). Songklanakarin J. Sci. Technol., 30: 687-692.

Choudhury D., Pal A., Sahu N., Kumar S., Das S., Mukherjee S. (2005). Dietary yeast RNA supplementation reduces mortality by Aeromonas hydrophila in rohu (Labeo rohita L.) juveniles. Fish Shellfish Immunol., 19: 281-291.

Cook M.T., Hayball P.J., Hutchinson W., Nowak B., Hayball J.D. (2001). The efficacy of a commercial $\beta$-glucan preparation, EcoActiva $^{\mathrm{TM}}$, on stimulating respiratory burst activity of head-kidney macrophages from pink snapper (Pagrus auratus), Sparidae. Fish Shellfish Immunol., 11: 661-672.

Cuesta A., Meseguer J., Esteban M. (2004). Total serum immunoglobulin M levels are affected by immunomodulators in seabream (Sparus aurata L.). Vet Immunol Immunopathol., 101: 203-210.

Dalmo R.A., Bøgwald J. (2008). B-glucans as conductors of immune symphonies. Fish Shellfish Immunol., 25: 384-396.

Dawood M., Koshio S., Ishikawa M., Yokoyama S., El Basuini M., Hossain M., Nhu T., Moss A., Dossou S., Wei H. (2017 a). Dietary supplementation of $\beta$-glucan improves growth performance, the innate immune response and stress resistance of red sea bream, Pagrus major. Aquac. Nutr., 23: 148-159.

Dawood M.A., Koshio S., El-Sabagh M., Billah M.M., Zaineldin A.I., Zayed M.M., Omar A.A.E.D. (2017 b). Changes in the growth, humoral and mucosal immune responses following $\beta$-glucan and vitamin $\mathrm{C}$ administration in red sea bream, Pagrus major. Aquaculture, 470: 214-222.

Dawood M.A., Koshio S., Esteban M.Á. (2018). Beneficial roles of feed additives as immunostimulants in aquaculture: a review. Rev. Aquacult., 10: 950-974.

Dawood M.A., Metwally A.E.S., El-Sharawy M.E., Atta A.M., Elbialy Z.I., Abdel-Latif H.M., Paray B.A. (2020). The role of $\beta$-glucan in the growth, intestinal morphometry, and immune-related gene and heat shock protein expressions of Nile tilapia (Oreochromis niloticus) under different stocking densities. Aquaculture, 523: 735205.

De Jesus R.B., Petit J., Pilarski F., Wiegertjes G.F., Koch J.F.A., de Oliveira C.A., Zanuzzo F.S. (2019). An early beta-glucan bath during embryo development increases larval size of Nile tilapia. Aquac Res., 50: 2012-2014.

De Mello M.M.M., de Faria C.d.F.P., Zanuzzo F.S., Urbinati E.C. (2019). $\beta$-glucan modulates cortisol levels in stressed pacu ( $P$ iaractus mesopotamicus) inoculated with heat-killed Aeromonas hydrophila. Fish Shellfish Immunol., 93: 1076-1083.
De Souza F.P., de Lima E.C.S., Pandolfi V.C.F., Leite N.G., FurlanMurari P.J., Leal C.N.S., Mainardi R.M., Suphoronski S.A., Favero L.M., Koch J.F.A. (2020). Effect of $\beta$-glucan in water on growth performance, blood status and intestinal microbiota in tilapia under hypoxia. Aquac. Rep., 17: 100369.

Divya M., Gopi N., Iswarya A., Govindarajan M., Alharbi N.S., Kadaikunnan S., Khaled J.M., Almanaa T.N., Vaseeharan B. (2020). $\beta$-glucan extracted from eukaryotic single-celled microorganism Saccharomyces cerevisiae: Dietary supplementation and enhanced ammonia stress tolerance on Oreochromis mossambicus. Microb. Pathog., 139: 103917.

Do Huu H., Sang H.M., Thuy N.T.T. (2016). Dietary $\beta$-glucan improved growth performance, Vibrio counts, haematological parameters and stress resistance of pompano fish, Trachinotus ovatus Linnaeus, 1758. Fish Shellfish Immunol., 54: 402-410.

Domenico J.D., Canova R., Soveral L.d.F., Nied C.O., Costa M.M., Frandoloso R., Kreutz L.C. (2017). Immunomodulatory effects of dietary $\beta$-glucan in silver catfish (Rhamdia quelen). Pesqui. Vet. Bras., 37: 73-78.

Engstad R.E., Robertsen B., Frivold E. (1992). Yeast glucan induces increase in lysozyme and complement-mediated haemolytic activity in Atlantic salmon blood. Fish Shellfish Immunol., 2: 287-297.

Gantner B.N., Simmons R.M., Canavera S.J., Akira S., Underhill D.M. (2003). Collaborative induction of inflammatory responses by dectin-1 and Toll-like receptor 2. J. Exp. Med., 197: 1107-1117.

Ghaedi G., Keyvanshokooh S., Azarm H.M., Akhlaghi M. (2015). Effects of dietary $\beta$-glucan on maternal immunity and fry quality of rainbow trout (Oncorhynchus mykiss). Aquaculture, 441: 78-83.

Ghaedi G., Keyvanshokooh S., Azarm H.M., Akhlaghi M. (2016). Proteomic analysis of muscle tissue from rainbow trout (Oncorhynchus mykiss) fed dietary $\beta$-glucan. Iran J. Vet. Res., 17: 184-189.

Guzmán-Villanueva L.T., Ascencio-Valle F., Macías-Rodríguez M.E., Tovar-Ramírez D. (2014 a). Effects of dietary $\beta$-1, 3/1, 6-glucan on the antioxidant and digestive enzyme activities of Pacific red snapper (Lutjanus peru) after exposure to lipopolysaccharides. Fish Physiol. Biochem., 40: 827-837.

Guzmán-Villanueva L.T., Tovar-Ramírez D., Gisbert E., Cordero H., Guardiola F.A., Cuesta A., Meseguer J., Ascencio-Valle F., Esteban M.A. (2014 b). Dietary administration of $\beta$-1, 3/1, 6-glucan and probiotic strain Shewanella putrefaciens, single or combined, on gilthead seabream growth, immune responses and gene expression. Fish Shellfish Immunol., 39: 34-41.

Herre J., Gordon S., Brown G.D. (2004). Dectin-1 and its role in the recognition of $\beta$-glucans by macrophages. Mol. Immunol., 40: 869-876.

Hisano H., Soares M.P., Luiggi F.G., Arena A.C. (2018). Dietary $\beta$-glucans and mannanoligosaccharides improve growth performance and intestinal morphology of juvenile pacu Piaractus mesopotamicus (Holmberg, 1887). Aquac.Int., 26: 213-223.

Holland M.C.H., Lambris J.D. (2002). The complement system in teleosts. Fish Shellfish Immunol., 12: 399-420.

Itami T., Takahashi Y., Nakamura Y. (1989). Efficacy of vaccination against vibriosis in cultured kuruma prawns Penaeus japonicus. J. Aquat. Anim. Health., 1: 238-242.

Ji L., Sun G., Li J., Wang Y., Du Y., Li X., Liu Y. (2017). Effect of dietary $\beta$-glucan on growth, survival and regulation of immune processes in rainbow trout (Oncorhynchus mykiss) infected by Aeromonas salmonicida. Fish Shellfish Immunol., 64: 56-67.

Ji L., Fu S., Ji R., Li X., Liu Y. (2019). $\beta$-glucan mitigated trinitrobenzene sulfonic acid-induced enteritis in the rainbow trout $(\mathrm{On}$ corhynchus mykiss). Aquaculture, 513: 734393.

Jiang C., Wang P., Li M., Liu S., Zhang S. (2016). Dietary $\beta$-glucan enhances the contents of complement component 3 and factor $\mathrm{B}$ in eggs of zebrafish. Dev. Comp. Immunol., 65: 107-113.

Joyce S.A., Kamil A., Fleige L., Gahan C.G. (2019). The cholesterollowering effect of oats and oat beta glucan: Modes of action and potential role of bile acids and the microbiome. Front. Nutr., 6: 171.

Kanlis G., Suzuki Y., Tauchi M., Numata T., Shirojo Y., Takashima F. (1995). Immunoglobulin in oocytes, fertilized eggs, and yolk sac larvae of red sea bream. Fish Sci., 61: 787-790.

Khanjani M.H., Sharifinia M. (2020). Biofloc technology as a promis- 
ing tool to improve aquaculture production. Rev. Aquacult., 12: 1836-1850.

Khanjani M.H., Sharifinia M. (2021). Production of Nile tilapia Oreochromis niloticus reared in a limited water exchange system: The effect of different light levels. Aquaculture, 542: 736912.

Khanjani M.H., Alizadeh M., Sharifinia M. (2020 a). Rearing of the Pacific white shrimp, Litopenaeus vannamei in a biofloc system The effects of different food sources and salinity levels. Aquac. Nutr., 26: 328-337.

Khanjani M.H., Sharifinia M., Hajirezaee S. (2020 b). Effects of different salinity levels on water quality, growth performance and body composition of Pacific white shrimp (Litopenaeus vannamei Boone, 1931) cultured in a zero water exchange heterotrophic system. Ann. Anim. Sci., 20: 1471-1486.

Khanjani M.H., Alizadeh M., Sharifinia M. (2021 a). Effects of different carbon sources on water quality, biofloc quality, and growth performance of Nile tilapia (Oreochromis niloticus) fingerlings in a heterotrophic culture system. Aquac.Int., 29: 307-321.

Khanjani M.H., Alizadeh M., Mohammadi M., Sarsangi Aliabad H. (2021 b). Biofloc system applied to Nile tilapia (Oreochromis niloticus) farming using different carbon sources: growth performance, carcass analysis, digestive and hepatic enzyme activity. Iran. J. Fish. Sci., 20: 490- 513.

Khanjani M.H., Alizadeh M., Mohammadi M., Sarsangi Aliabad H. (2021 c). The effect of adding molasses in different times on performance of Nile tilapia (Oreochromis niloticus) raised in a lowsalinity biofloc system. Ann. Anim. Sci., 21: 1-20.

Kobayashi M., Msangi S., Batka M., Vannuccini S., Dey M.M., Anderson J.L. (2015). Fish to 2030: the role and opportunity for aquaculture. Aquac. Econ. Manag., 19: 282-300.

Kumar S., Sahu N., Pal A., Choudhury D., Yengkokpam S., Mukherjee S. (2005). Effect of dietary carbohydrate on haematology, respiratory burst activity and histological changes in L. rohita juveniles. Fish Shellfish Immunol., 19: 331-344.

Lam K., Cheung P. (2013). Non-digestible long chain beta-glucans as novel prebiotics. Bioact. Carbohydr. Diet. Fibre, 2: 45-64.

Lara-Flores M., Olvera-Novoa M.A., Guzmán-Méndez B.E., LópezMadrid W. (2003). Use of the bacteria Streptococcus faecium and Lactobacillus acidophilus, and the yeast Saccharomyces cerevisiae as growth promoters in Nile tilapia (Oreochromis niloticus) Aquaculture, 216: 193-201.

Lee J.H., Kim J.W., Kang Y.J., Ko D.W., Kim J.M., Choi S.H., Park K.H. (2018). Effects of $\beta$-1,3-glucan on innate immunity responses and mortality induced by Vibrio harveyi, hemorrhagic septicemia virus, or Miamiensis avidus in the olive flounder Paralichthys olivaceus. Aquacult. Int., 26: 743-756.

Lee C.L., Chang C.C., Kuo H.W., Cheng W. (2020 a). Pectin of cacao pod husk, an efficient immunostimulant for white shrimp, Litopenaeus vannamei. Fish Shellfish Immunol., 107: 357-366.

Lee P.T., Liao Z.H., Huang H.T., Chuang C.Y., Nan F.H. (2020 b). $\beta$-glucan alleviates the immunosuppressive effects of oxytetracycline on the non-specific immune responses and resistance against Vibrio alginolyticus infection in Epinephelus fuscoguttatus $\times$ Epinephelus lanceolatus hybrids. Fish Shellfish Immunol., 100: $467-475$.

Li P., Gatlin III D.M. (2003). Evaluation of brewers yeast (Saccharomyces cerevisiae) as a feed supplement for hybrid striped bass (Morone chrysops $\times$ M. saxatilis). Aquaculture, 219: 681-692.

Li P., Gatlin III D.M. (2004). Dietary brewers yeast and the prebiotic Grobiotic $^{\mathrm{TM}} \mathrm{AE}$ influence growth performance, immune responses and resistance of hybrid striped bass (Morone chrysops $\times$ M. saxatilis) to Streptococcus iniae infection. Aquaculture, 231: 445-456.

Li P., Gatlin III D.M. (2005). Evaluation of the prebiotic GroBiotic ${ }^{\circledR}-A$ and brewers yeast as dietary supplements for sub-adult hybrid striped bass (Morone chrysops $\times$ M. saxatilis) challenged in situ with Mycobacterium marinum. Aquaculture, 248: 197-205.

Li H., Xu C., Zhou L., Dong Y., Su Y., Wang X., Qin J.G., Chen L., Li E. (2019). Beneficial effects of dietary $\beta$-glucan on growth and health status of Pacific white shrimp Litopenaeus vannamei at low salinity. Fish Shellfish Immunol., 91: 315-324.

Librán-Pérez M., Costa M.M., Figueras A., Novoa B. (2018). $\beta$-glucan administration induces metabolic changes and differential surviv- al rates after bacterial or viral infection in turbot (Scophthalmus maximus). Fish Shellfish Immunol., 82: 173-182.

Lin S., Pan Y., Luo L., Luo L. (2011). Effects of dietary $\beta$-1,3-glucan, chitosan or raffinose on the growth, innate immunity and resistance of koi (Cyprinus carpio koi). Fish Shellfish Immunol., 31: 788-794

Liu H., Xie M., Nie S. (2020). Recent trends and applications of polysaccharides for microencapsulation of probiotics. Food Frontiers, 1: 45-59.

Løvoll M., Kilvik T., Boshra H., Bøgwald J., Sunyer J.O., Dalmo R.A. (2006). Maternal transfer of complement components C3-1, C3-3, $\mathrm{C} 3-4, \mathrm{C} 4, \mathrm{C} 5, \mathrm{C} 7, \mathrm{Bf}$, and Df to offspring in rainbow trout $\mathrm{On}$ corhynchus mykiss). Immunogenetics, 58: 168-179.

Lu D.L., Limbu S.M., Lv H.B., Ma Q., Chen L.Q., Zhang M.L., Du Z.Y. (2019). The comparisons in protective mechanisms and efficiencies among dietary $\alpha$-lipoic acid, $\beta$-glucan and l-carnitine on Nile tilapia infected by Aeromonas hydrophila. Fish Shellfish Immunol., 86: 785-793.

Ma K., Bao Q., Wu Y., Chen S., Zhao S., Wu H., Fan J. (2020). Evaluation of microalgae as immunostimulants and recombinant vaccines for diseases prevention and control in aquaculture. Front. Bioeng. Biotechnol., 8: 1331.

Medina-Gali R.M., del Mar Ortega-Villaizan M., Mercado L., Novoa B., Coll J., Perez L. (2018). Beta-glucan enhances the response to SVCV infection in zebrafish. Dev. Comp. Immunol., 84: $307-314$

Meena D., Das P., Kumar S., Mandal S., Prusty A., Singh S., Akhtar M., Behera B., Kumar K., Pal A. (2013). Beta-glucan: an ideal immunostimulant in aquaculture (a review). Fish Physiol. Biochem., 39: 431-457.

Miest J.J., Arndt C., Adamek M., Steinhagen D., Reusch T.B. (2016). Dietary $\beta$-glucan (MacroGard ${ }^{\circledR}$ ) enhances survival of first feeding turbot (Scophthalmus maximus) larvae by altering immunity, metabolism and microbiota. Fish Shellfish Immunol., 48: 94-104.

Misra C.K., Das B.K., Mukherjee S.C., Pattnaik P. (2006). Effect of multiple injections of $\beta$-glucan on non-specific immune response and disease resistance in Labeo rohita fingerlings. Fish Shellfish Immunol., 20: 305-319.

Mohan K., Ravichandran S., Muralisankar T., Uthayakumar V., Chandirasekar R., Seedevi P., Abirami R.G., Rajan D.K. (2019). Application of marine-derived polysaccharides as immunostimulants in aquaculture: A review of current knowledge and further perspectives. Fish Shellfish Immunol., 86: 1177-1193.

Mokhbatly A.A.A., Assar D.H., Ghazy E.W., Elbialy Z., Rizk S.A., Omar A.A., Gaafar A.Y., Dawood M.A. (2020). The protective role of spirulina and $\beta$-glucan in African catfish (Clarias gariepinus) against chronic toxicity of chlorpyrifos: hemato-biochemistry, histopathology, and oxidative stress traits. Environ. Sci. Pollut. Res., 27: 31636-31651

Montoya L.N.F., Favero G.C., Zanuzzo F.S., Urbinati E.C. (2018). Distinct $\beta$-glucan molecules modulates differently the circulating cortisol levels and innate immune responses in matrinxã (Brycon amazonicus). Fish Shellfish Immunol., 83: 314-320.

Morales-López R., Auclair E., Garcia F., Esteve-Garcia E., Brufau J. (2009). Use of yeast cell walls; $\beta$-1,3/1,6-glucans; and mannoproteins in broiler chicken diets. Poultry Sci., 88: 601-607.

Morgan B.P., Marchbank K.J., Longhi M.P., Harris C.L., Gallimore A.M. (2005). Complement: central to innate immunity and bridging to adaptive responses. Immunol. Lett., 97: 171-179.

Mueller A., Raptis J., Rice P.J., Kalbfleisch J.H., Stout R.D., Ensley H.E., Browder W., Williams D.L. (2000). The influence of glucan polymer structure and solution conformation on binding to $(1 \rightarrow$ $3)-\beta$-D-glucan receptors in a human monocyte-like cell line. Glycobiology, 10: 339-346.

Neamat-Allah A.N., Abd El Hakim Y., Mahmoud E.A. (2020). Alleviating effects of $\beta$-glucan in Oreochromis niloticus on growth performance, immune reactions, antioxidant, transcriptomics disorders and resistance to Aeromonas sobria caused by atrazine. Aquacult. Res., 51: 1801-1812.

Nguyen T.M., Mandiki S.N., Tran T.N.T., Larondelle Y., Mellery J., Mignolet E., Cornet V., Flamion E., Kestemont P. (2019). Growth performance and immune status in common carp Cyprinus carpio 
as affected by plant oil-based diets complemented with $\beta$-glucan. Fish Shellfish Immunol., 92: 288-299.

Nieves-Rodríguez K.N., Álvarez-González C.A., Peña-Marín E.S., Vega-Villasante F., Martínez-García R., Camarillo-Coop S., Tovar-Ramírez D., Guzmán-Villanueva L.T., Andree K.B., Gisbert E. (2018). Effect of $\beta$-glucans in diets on growth, survival, digestive enzyme activity, and immune system and intestinal barrier gene expression for tropical gar (Atractosteus tropicus) juveniles. Fishes, 3: 27.

Nonaka M., Smith S.L. (2000). Complement system of bony and cartilaginous fish. Fish Shellfish Immunol., 10: 215-228.

Ochoa-Álvarez N.A., Casillas-Hernández R., Magallón-Barajas F.J., Ramirez-Orozco J.M., Carbajal-Millan E. (2021). Protector effect of beta-glucans from shrimp pond-related yeasts in Penaeus vannamei rearing under white spot syndrome virus presence. Lat. Am. J. Aquat. Res., 49: 18-28.

Ogier de Baulny M., Quentel C., Fournier V., Lamour F., Le Gouvello R. (1996). Effect of long-term oral administration of beta-glucan as an immunostimulant or an adjuvant on some non-specific parameters of the immune response of turbot Scophthalmus maximus. Dis. Aquat. Org., 26: 139-147.

Ogundele M.O. (2001). Role and significance of the complement system in mucosal immunity: particular reference to the human breast milk complement. Immunol. Cell Biol., 79: 1-10.

Ooi V.E., Liu F. (2000). Immunomodulation and anti-cancer activity of polysaccharide-protein complexes. Curr. Med. Chem., 7: 715-729.

Ortuño J., Cuesta A., Rodríguez A., Esteban M.A., Meseguer J. (2002). Oral administration of yeast, Saccharomyces cerevisiae, enhances the cellular innate immune response of gilthead seabream (Sparus aurata L.). Vet. Immunol. Immunopathol., 85: 41-50.

Pauly D., Zeller D. (2017). Comments on FAOs state of world fisheries and aquaculture (SOFIA 2016). Mar. Policy, 77: 176-181.

Picchitti S., Scapigliati G., Fanelli M., Barbato F., Canese S., Mastrolla L., Mazzini M., Abelli L. (2001). Sex-related variations of serum immunoglobulins during reproduction in gilthead sea bream and evidence for a transfer from the female to the eggs. J. Fish Biol., 59: 1503-1511.

Pilarski F., de Oliveira C.A.F., de Souza F.P.B.D., Zanuzzo F.S. (2017). Different $\beta$-glucans improve the growth performance and bacterial resistance in Nile tilapia. Fish Shellfish Immunol., 70: 25-29.

Raa J. (2000). The use of immune-stimulants in fish and shellfish feeds. In: Advance en Nutricion Acuicola V, Cruz-Suarez L.E., Ricque-Marie D., Tapia-Salazar M., Olvera-Novoa M.A., CiveraCerecedo R. (eds). Proc. Memorias del V Simposium Internacional de Nutrcion Acouicola. Merida, Yucatan, pp. 47-56.

Ringø E., Olsen R.E., Vecino J.G., Wadsworth S., Song S. (2012). Use of immunostimulants and nucleotides in aquaculture: a review. J. Mar. Sci. Res. Dev., 2: 104.

Roberti Filho F.D.O., Koch J.F.A., Wallace C., Leal M.C. (2019). Dietary $\beta$-1,3/1,6-glucans improve the effect of a multivalent vaccine in Atlantic salmon infected with Moritella viscosa or infectious salmon anemia virus. Aquac.Int., 27: 1825-1834.

Rodríguez F.E., Valenzuela B., Farías A., Sandino A.M., Imarai M. (2016). $\beta-1,3 / 1,6$-glucan-supplemented diets antagonize immune inhibitory effects of hypoxia and enhance the immune response to a model vaccine. Fish Shellfish Immunol., 59: 36-45.

Rop O., Mlcek J., Jurikova T. (2009). Beta-glucans in higher fungi and their health effects. Nutr. Rev., 67: 624-631.

Ross D.A., Wilson M.R., Miller N.W., Clem L.W., Warr G.W., Ross D.A., Wilson M.R., Miller N.W., Clem L.W., Warr G.W. (1998). Evolutionary variation of immunoglobulin $\mu$ heavy chain RNA processing pathways: origins, effects, and implications. Immunol. Rev., 166: 143-151.

Russo R., Yanong R.P., Mitchell H. (2006). Dietary beta-glucans and nucleotides enhance resistance of red-tail black shark (Epalzeorhynchos bicolor, fam. Cyprinidae) to Streptococcus iniae infection. J. World Aquac. Soc., 37: 298-306.

Sabioni R.E., Zanuzzo F.S., Gimbo R.Y., Urbinati E.C. (2020). $\beta$-glucan enhances respiratory activity of leukocytes suppressed by stress and modulates blood glucose levels in pacu (Piaractus mesopotamicus). Fish Physiol. Biochem., 46: 629-640.
Sahoo P., Mukherjee S. (2001). Effect of dietary $\beta-1,3$ glucan on immune responses and disease resistance of healthy and aflatoxin B1-induced immunocompromised rohu (Labeo rohita Hamilton). Fish Shellfish Immunol., 11: 683-695.

Sahoo P., Kumari J., Mishra B. (2005). Non specific immune responses in juveniles of Indian major carps. J. Appl. Ichthyol., 21: 151-155.

Sakai M. (1999). Current research status of fish immunostimulants. Aquaculture, 172: 63-92.

Sang H.M., Fotedar R. (2010). Effects of dietary $\beta$-1,3-glucan on the growth, survival, physiological and immune response of marron, Cherax tenuimanus (Smith, 1912). Fish Shellfish Immunol., 28: 957-960.

Scapigliati G., Scalia D., Marras A., Meloni S., Mazzini M. (1999). Immunoglobulin levels in the teleost sea bass Dicentrarchus labrax (L.) in relation to age, season, and water oxygenation. Aquaculture, 174: 207-212.

Sealey W., Barrows F., Hang A., Johansen K., Overturf K., LaPatra S., Hardy R. (2008). Evaluation of the ability of barley genotypes containing different amounts of $\beta$-glucan to alter growth and disease resistance of rainbow trout Oncorhynchus mykiss. Anim. Feed Sci. Technol., 141: 115-128.

Selim K.M., Reda R.M. (2015). Beta-glucans and mannan oligosaccharides enhance growth and immunity in Nile tilapia. N. Am. J. Aquac., 77: 22-30.

Sherif A.H., Mahfouz M.E. (2019). Immune status of Oreochromis niloticus experimentally infected with Aeromonas hydrophila following feeding with 1,3 $\beta$-glucan and levamisole immunostimulants. Aquaculture, 509: 40-46.

Sirimanapong W., Adams A., Ooi E.L., Green D.M., Nguyen D.K., Browdy C.L., Collet B., Thompson K.D. (2015). The effects of feeding immunostimulant $\beta$-glucan on the immune response of Pangasianodon hypophthalmus. Fish Shellfish Immunol., 45: 357-366.

Siwicki A.K., Anderson D.P., Rumsey G.L. (1994). Dietary intake of immunostimulants by rainbow trout affects non-specific immunity and protection against furunculosis. Vet. Immunol. Immunopathol., 41: 125-139.

Soares M.P., Oliveira F.C., Cardoso I.L., Urbinati E.C., de Campos C.M., Hisano H. (2018). Glucan-MOS ${ }^{\circledR}$ improved growth and innate immunity in pacu stressed and experimentally infected with Aeromonas hydrophila. Fish Shellfish Immunol., 73: 133-140.

Soltanian S., Stuyven E., Cox E., Sorgeloos P., Bossier P. (2009). Betaglucans as immunostimulant in vertebrates and invertebrates. Crit. Rev. Microbiol., 35: 109-138.

Sonck E., Stuyven E., Goddeeris B., Cox E. (2010). The effect of $\beta$-glucans on porcine leukocytes. Vet. Immunol. Immunopathol., 135: 199-207.

Tayyab R., Khan N., Ashraf M., Khalique A., Rasool F., Azmat H., Abbas S., Mahmood Anjum K., Hameed Mughal D., Javed Iqbal K. (2019). A comparative study of beta glucan and plant stimulants on the growth, histology and immune response of Labeo rohita. Iran. J. Fish. Sci., 18: 862-872.

Terzi E., Kucukkosker B., Bilen S., Kenanoglu O.N., Corum O., Ozbek M., Parug S.S. (2020). A novel herbal immunostimulant for rainbow trout (Oncorhynchus mykiss) against Yersinia ruckeri. Fish Shellfish Immunol., 110: 55-66.

Thompson K.D. (2017). Chapter 1 - Immunology: Improvement of Innate and Adaptive Immunity. In: Fish Diseases, Jeney G. (ed.). Academic Press, pp. 1-17.

Tovar D., Zambonino J., Cahu C., Gatesoupe F., Vázquez-Juárez R., Lésel R. (2002). Effect of live yeast incorporation in compound diet on digestive enzyme activity in sea bass (Dicentrarchus labrax) larvae. Aquaculture, 204: 113-123.

Travassos L.R., Taborda C.P. (2017). Linear epitopes of Paracoccidioides brasiliensis and other fungal agents of human systemic mycoses as vaccine candidates. Front. Immunol., 8: 224.

Velazquez-Carriles C., Macias-Rodríguez M.E., Carbajal-Arizaga G.G., Silva-Jara J., Angulo C., Reyes-Becerril M. (2018). Immobilizing yeast $\beta$-glucan on zinc-layered hydroxide nanoparticle improves innate immune response in fish leukocytes. Fish Shellfish Immunol., 82: 504-513.

Verlhac V., Obach A., Gabaudan J., Schuep W., Hole R. (1998). Im- 
munomodulation by dietary vitamin $\mathrm{C}$ and glucan in rainbow trout (Oncorhynchus mykiss). Fish Shellfish Immunol., 8: 409-424.

Waché Y., Auffray F., Gatesoupe F.J., Zambonino J., Gayet V., Labbé L., Quentel C. (2006). Cross effects of the strain of dietary Saccharomyces cerevisiae and rearing conditions on the onset of intestinal microbiota and digestive enzymes in rainbow trout, $\mathrm{On}$ chorhynchus mykiss, fry. Aquaculture, 258: 470-478.

Wang Z., Zhang S., Wang G., An Y. (2008). Complement activity in the egg cytosol of zebrafish Danio rerio: evidence for the defense role of maternal complement components. PloS One, 3: e1463.

Wang P., Jiang C., Liu S., Cui P., Zhang Y., Zhang S. (2017 a). Transgenerational enhancement of C-type lysozyme level in eggs of zebrafish by dietary $\beta$-glucan. Dev. Comp. Immunol., 74: 25-31.

Wang W., Sun J., Liu C., Xue Z. (2017 b). Application of immunostimulants in aquaculture: current knowledge and future perspectives. Aquac Res., 48: 1-23.

Wang Y., Harding S.V., Thandapilly S.J., Tosh S.M., Jones P.J., Ames N.P. (2017 c). Barley $\beta$-glucan reduces blood cholesterol levels via interrupting bile acid metabolism. Br. J. Nutr., 118: 822-829.

Whittington R., Lim C., Klesius P.H. (2005). Effect of dietary $\beta$-glucan levels on the growth response and efficacy of Streptococcus iniae vaccine in Nile tilapia, Oreochromis niloticus. Aquaculture, 248: $217-225$.
Wu Y.S., Liau S.Y., Huang C.T., Nan F.H. (2016). Beta 1,3/1,6-glucan and vitamin $\mathrm{C}$ immunostimulate the non-specific immune response of white shrimp (Litopenaeus vannamei). Fish Shellfish Immunol., 57: 269-277.

Yamamoto F.Y., Yin F., Rossi Jr W., Hume M., Gatlin III D.M. (2018), $\beta-1,3$ glucan derived from Euglena gracilis and Algamune ${ }^{\mathrm{TM}}$ enhances innate immune responses of red drum (Sciaenops ocellatus L.). Fish Shellfish Immunol., 77: 273-279.

Yamamoto F.Y., Castillo S., de Cruz C.R., Chen K., Hume M.E., Gatlin III D.M. (2020). Synergistic effects of the $\beta-1,3$ glucan paramylon and vitamin $\mathrm{C}$ on immunological responses of hybrid striped bass (Morone chrysops $\times$ M. saxatilis) were pronounced in vitro but more moderate in vivo. Aquaculture, 526: 735394.

Zeng L., Wang Y.H., Ai C.X., Zheng J.L., Wu C.W., Cai R. (2016). Effects of $\beta$-glucan on ROS production and energy metabolism in yellow croaker (Pseudosciaena crocea) under acute hypoxic stress. Fish Physiol. Biochem., 42: 1395-1405.

Zhu F., Du B., Xu B. (2016). A critical review on production and industrial applications of beta-glucans. Food Hydrocoll., 52: 275-288.

Received: 5 VII 2021

Accepted: 11 X 2021 